\title{
Tindak Pidana Pengolahan, dan Peredaran dan atau Pemasaran Hasil Perkebunan yang Membahayakan Kesehatan dan Keselamatan Manusia
}

\section{Criminal Processing, And The Circulation And Or Marketing of Plantation Products That Harm To Human Health And Safety}

\author{
Yovi Wicaksana Putra, Kartina Pakpahan, Lusi Feny Epriliani Panjaitan* \& \\ Arta Hot Manullang
}

Prodi Ilmu Hukum, Fakultas Hukum, Universitas Prima Indonesia

Diterima: 01 September 2020 ; Direview: 02 September 2020; Disetujui: 13 September 2020 *Coresponding Email: lusifenypanjaitan@yahoo.co.id

Negara Indonesia kaya akan hasil bumi sebagaian besar masyarakat bermata pencaharian bertani khususnya hasil perkebunan. Tidak jarang hasil perkebunan tidak memenuhi standart mutu, memenuhi kesehatan dan keselamatan masyarakat. Tujuan penelitian menganalisis bentuk Perlindungan Hukum kepada konsumen, kriteria hasil perkebunan, hukuman yang diberikan kepada pelaku tindak pidana Pengolahan, Peredaran dan atau Pemasaran Hasil Perkebunan Membahayakan Kesehatan Dan Keselamatan. Menggunakan metode penelitian yuridis normatif dengan menelaah permasalahan utama berdasarkan data yang diperoleh. Penelitian ini menggunakan sifat deskriptif analitis guna untuk memberikan gambaran terhadap objek yang sedang diteliti. Kesimpulan bahwa pengolahan, peredaran dan pemasaran hasil perkebunan telah diatur dalam pasal 77 jo 110 UU No 39 Tahun 2014 tentang perkebunan dan UU No 8 Tahun 1999 tentang Perlindungan Konsumen. Peraturan Badan Pengawasan Obat dan Makanan Nomor 28 tahun 2019 Tentang Bahan Penolong dalam Pengolahan Pangan. Penggunaan bahan tambahan atau bahan penolong yang digunakan tidak sesuai dengan persyaratan keamanan dan mutu atau pemakaian yang melebihi memberikan dampak tidak baik bagi kesehatan dan keselamatan manusia. Pelaku usaha yang melakukan perbuatan melanggar dalam pengolahan, pengedaran dan atau pemasaran yang merugikan kesehatan dan keselamatan manusia yang menimbulkan persaingan usaha tidak sehat dan akan diberikan hukuman berupa sanksi pidana dan sanksi adminstrasi

Kata Kunci: Pengolahan, Peredaran dan atau Pemasaran, Hasil Perkebunan, Berbahaya bagi Manusia

\begin{abstract}
The Indonesian country is rich in farmed communities, especially agricultural livelihoods. It is not rare that farm yields fail to meet its quality standards, satisfy the health and safety of masvardized research purposes, which are assessed the form of legal protection to consumers, plantation criteria, punishments that are given to criminal processing, distribution and or or marketing of health and safety estates. Using normatif juridical research methods by studying the major issues based on data obtained. The study USES analytical descriptive properties to give swift response to the objects being examined. The conclusion that the processing, distribution and marketing of plantation products has been established in article 77 Jo 110 of the 2014 section no. 39 on plantation and section no. 8 of 1999 on consumer protection. Food and drug administration regulation no. 28 stages 2019 of food-care agents. The use of additives or helper that is used does not fit security requirements and quality or use that exceeds have adverse effects on human health and safety. At the risk of public health and safety, non-performing consumers will be punished by the da's criminal penalties
\end{abstract} Keywords : the processing, circulation and or marketing, of agricultural product, are dangerous to humans

How to cite: Putra, Y.W. Pakpahan, K. Panjaitan, L.F.E. \& Manullang, A.H. (2020), Tindak Pidana Pengolahan, dan Peredaran dan atau Pemasaran Hasil Perkebunan yang Membahayakan Kesehatan dan Keselamatan Manusia, Journal of Education, Humaniora and Social Sciences (JEHSS), 3(2): 427-433 


\section{PENDAHULUAN}

Sebagian besar masyarakat Indonesia dengan mata pencaharian berasal dari hasil perkebunan, dengan hasil kekayaan bumi yang berlimpah salah satunya adalah Indonesia, yang dimana mata pencaharian masyarakat masih lebih besar dari hasil perkebunan. Menurut UU No 39 Tahun 2014 mengenai Perkebunan yang menjelaskan bahwa perkebunan yang merupakan segala kegiatan pengolahan dan pemasaran yang berasal dari SDA dan SDM yang terkait pada budidaya dan hasil panen tanaman perkebunan, yang mempunyai tujuan dan jenis pengolahannya ditetapkan pada usaha perkebunan yang akan menghasilkan barang dan/atau jasa perkebunan.

Hasil Perkebunan yang dimaksud adalah suatu produk perkebunan yang didalam pengolahannya terdapat produk utama dan olahan guna memanjangkan waktu daya simpan pada produk tersebut (UU Perkebunan), hasil perkebunan tersebut akan melalui beberapa proses sebelum sampai ketangan konsumen, yaitu dengan melalui proses pengelolahan, pengedaran dan pemasaran (Kadir, 2018; Abdina, 2019; Winda et al, 2020; Hartono et al., 2020). Pengolahan Hasil Perkebunan merupakan rangkaian yang dilakukan terna memenuhi standart mutu perpanjangan daya simpan, mengurangi kerusakan, dan memperoleh hasil optimal guna mencapai nilai tambah yang lebih tinggi hal ini sebagai mana diatur didalam pasal 1 ayat 12 Undang-Undang Nomor 39 Tahun 2014 tentang Perkebunan.(Paralegal, 2014)

Apabila hasil perkebunan dalam pengolahan, peredaran dan atau pemasaran hasil perkebunan yang dapat menimbulkan gangguan kesehatan, membahayakan kesehatan dan keselamatan merupakan perbuatan pidana sebagaimana yang diatur didalam pasal 77 Undangundang Perkebunan. Perbuatan tersebut dapat merugikan diri sendiri maupun orang lain yang memberikan efek membahayakan kesehatan, mengakibatkan timbulnya penyakit maupun kombinasi penyakit lainnya. Kepada pelaku dapat diberikan sanksi administrasi sebagaimana diatur dalam pasal 75 ayat (2) Undang-undang Perkebunan.

Hukum yang berfungsi sebagai perlindungan yang harus dijalankan secara profesional dan dapat berlangsung normal, damai, dan bermanfaat bagi masyarakat guna dalam menghasilkan keadaan yang damai dan tentram. Hukum yang dapat melindungi setiap individu dalam kenyataan dan sesungguhnya dalam perlindungan hukum yang kokoh akan terwujud dan memiliki seuatu tujuan hukum yang secara umum yaitu ketertiban, keamanan, dan keadilan.

Perlindungan hukum merupakan suatu tindakan yang dilakukan bertujuan dalam melindungi subyek hukum dengan melalui peraturan perundang-undangan yang sedang berlaku dan diharuskan dengan adanya suatu sanksi. Dapat dibedakan menjadi dua (Muchsin, 2003), yaitu: Perlindungan Hukum Preventif dan Perlindungan Hukum Represif.

Secara hierarki tingkatan peraturan perundang-undang dimulai dari ketentuan lebih tinggi dan disusul dengan tingkatan Peraturan yang lebih rendah. Undang-Undang yang lebih rendah. Dalam Peraturan Pemerintah Republik Indonesia Nomor 58 Tahun 2001 Pasal 1 ayat 1 tentang Pembinaan Dan Pengawasan Penyelenggara Perlindungan hukum yang menyebutkan, bahwa perlindungan konsumen yang merupakan suatu tindakan yang telah diberikan untuk mejamin dalam memperoleh kepastian hukum. (Peraturan Pemerintah, 2001). Bertujuan untuk melindungi diri dari akses jahat dalam pemakaian barang/jasa, mengangkat harkat dan martabat konsumen dan meningkatkan pemerdayaan konsumen dalam memilih dan menentukan hakhaknya dan dalam transparansi informasi yang diberikan dan dapat memberikan kesadaran kepada pelaku usaha akan pentingnya perlindungan konsumen dan dapat meningkatkan kualitas barang dan/atau jasa yang menjamin kelangsungan usaha produksi, kesehatan, kenyamanan, dan keselamatan pada konsumen", yang tertuang didalam pasal 3 UU No 8 tahun 1999 tentang Perlindungan Konsumen. Menurut AZ. Nasution ada beberapa batasan tentang Konsumen, yakni konsumen, konsumen antara dan konsumen akhir (Nasution" 2001).

Pengertian pemasaran menurut Stanton suatu aktivitas usaha merencanakan promosi, distirbuasi dan menentukan harga barang atau jasa sampai kepada pembeli, maupun pembeli potensial (Stanton, 1991). Dalam melakukan usaha perkebunan, pelaku usaha harus terlebih dahulu memiliki izin usaha perkebunan yang mewajibkan memenuhi syarat-syarat yang telah 
diatur pada pasal 10 Keputusan Menteri Pertanian Nomor 357 Tahun 2002 tentang pedoman perizinan usaha perkebunan, yaitu pendirian akte dan perubahan, NPWP, Keterangan Domisili, Rencana kerja, Rekomendasi lokasi, Ketersediaan lahan, Lahan dari Kepala Dinas, Pernyataan penguasaan lahan perusahaan, Pola pengembangan, Peta calon lokasi, dokumen AMDAL dari komisi AMDAL Daerah. (Keputusan Menteri Pertanian, 2002).

Pelaku usaha yang menjalankan usaha dilarang malakukan perbuatan yang dapat merugikan kesehatan dan keselamatan manusia seperti memalsukan kemasan, dan menggunakan bahan penolong/bahan tambahan, dan mencampurkan dengan benda atau bahan lain dalam proses pengolahannya yang dapat merusak fungsi lingkungan hidup, dan menimbulkan persaingan usaha yang tidak sehat tertulis dalam pasal 77 UU No 39 Tahun 2014 tentang Perkebunan.

Perbuatan yang Memalsukan dan/atau kemasan Hasil Perkebunan tertulis dalam pasal 77 UU perkebunan adalah suatu perbuatan serupa dengan penipuan, yang kejahatannya seperti pemberdayaan orang lain pada penggunaan benda yang diperoleh dalam pemalsuan. Pada kepastian hukum pidana, memiliki bentuk kejahatan dalam pemalsuan yaitu seperti: sumpah palsu,pemalsuan uang, pemalsuan merek dan materai, dan pemalsuan surat,dan pemalsuan kemasan. Yang sering terjadi di dalam suatu tempat produksi demi mendapatkan keuntungan besar dengan menggunakan kemasan produk lain yang lebih terkenal tetapi dengan isi yang tidak sesuai produk aslinya (Juliyanti, 2019), beraneka macam produk yang dipalsukan seperti produk kosmetik, makanan dan minuman. Tindak pidana Pemalsuan kemasan yang dimana setiap orang yang dengan sengaja membuka kemasan pada produk dengan tujuan isi dari produk tersebut dikemas kembali dan diperdagangkan lagi dan perbuatan tersebut akan dikenakan pidana penjara paling lama lima tahun atau pemberian denda sebanyak sepuluh miliar rupiah yang tertulis dalam Pasal 139 UU No 18 Tahun 2012 Tentang Pangan.(UU Pangan).

Beberapa bahan tambahan yang digunakan dalam pengolahan makanan Bahan Tambahan Pangan dimaksud adalah Asam borat, kalium klorat, kloramfenikol, minyak nabati yang dibrominasi, formalin, dan kalium bromat (Permenkes, 2012). Khususnya untuk bahan pewarna yang dilarang digunakan yang ditetapkan dalam Permenkes Republik No. 239/Menkes/Per/V/1985 tentang zat warna tertentu yang dinyatakan sebagai bahan berbahaya (Permenkes, 1985).

\section{METODE PENELITIAN}

Dalam penelitian ini menggunakan metode yuridis normatif,menelaah permasalahan utama dengan menggunakan referensi peraturan perundang-undangan, artikel penelitian, dengan media perantara arsip, buku, catatan, bukti artikel yang dipublikasikan ataupun tidak dipublikasikan (Kanalinfo, 2016). Dengan menggunakan deskripstif analisis untuk memberikan sebuah gambaran terhadap objek yang diteliti (Sugiyono, 2019) yakni dengan memberi penjelasan terhadap data yang ada dengan menggunakan kata-kata ataupun pernyataan (idtesis.com, 2013). Sumber bahan hukum diperoleh dari sumber hukum primer, sekunder dan tersier.

\section{HASIL DAN PEMBAHASAN}

\section{Kriteria Hasil Perkebunan yang Membahayakan Kesehatan dan Keselamatan Manusia}

Hasil perkebunan yang merupakan produk tanaman perkebunan dalam proses pengolahan terdapat produk utama, yang dapat memperpanjang daya simpan produk yang diolah menjadi beraneka ragam produk yang dihasilkan, yaitu seperti makanan dan minuman, kosmetik, dan bahan bakar. Hasil perkebunan tersebut dapat juga membahayakan kesehatan dan keselamatan pada konsumen karena adanya pelanggaran yang dilakukan oleh pelaku usaha dalam proses pengolahan, peredaran dan pemasaran yang tercantum pada Pasal 77 UU No 39 Tahun 2014 yang mana dalam proses pengolahannya sering menggunakan bahan penolong atau bahan tambahan yang dapat mempengaruhi sifat atau bentuk pangan dan memberikan keuntungan besar bagi pelaku usaha, bahan tambahan tersebut merupakan bahan tambahan yang dilarang 
digunakan dalam pangan karena dapat membahayakan, seperti pewarna tekstil, Asam borat dan senyawanya (boraks) dan formalin.

Pangan yang dimaksud adalah sumber hayati produk yang berasal dari pertanian,perkebunan, kehutanan,perikanan, peternakan,perairan, dan air yang dapat diolah maupun tidak untuk digunakan sebagai makanan dan minuman yang akan dikonsumsi manusia termasuk bahan tambahan pangan dan bahan lainnya yang akan digunakan dalam proses pembuatan makanan dan minuman yang tertuang dalam Peraturan Pemerintah Nomor 86 tahun 2019 tentang Keamanan Pangan. (Peraturan Pemerintah, 2019). Dalam proses pengolahan hasil perkebunan sering kali para pelaku usaha mencampurkan bahan penolong atau bahan tambahan yang tidak layak dikonsumsi kedalam produk, menurut Peraturan Badan Pengawasan Obat dan Makanan Nomor 28 Tahun 2019 Pasal 1 ayat 2 tentang Bahan Penolong dalam Pengolahan Pangan (Peraturan BPOM), yang akan digunakan dalam pengolahan pangan tetapi tidak lazim untuk dikonsumsi, dan apabila tidak dihindari maka akan menimbulkan resiko terhadap kesehatan serta tidak mempunyai fungsi teknologi.

Penggunaan bahan penolong atau tambahan dalam proses pengolahannya wajib memenuhi persyaratan untuk keamanan dan mutu agar tidak berdampak buruk bagi kesehatan manusia seperti yang tertuang dalam BPOM No 28 tahun 2019 dalam Pasal 18 ayat 3, dan ayat 5 Tentang Bahan Penolong dalam Pengolahan Pangan yang menyebutkan bahwa:

\begin{tabular}{|c|c|c|}
\hline \multicolumn{3}{|c|}{$\begin{array}{c}\text { Peraturan Bahan Pengawasan Obat dan Makanan Nomor } 28 \text { tahun } 2019 \text { Tentang } \\
\text { Bahan Penolong dalam Pengolahan Pangan }\end{array}$} \\
\hline Ayat 3 & $\begin{array}{l}\text { Persyaratan Bahan } \\
\text { Penolong Golongan } \\
\text { Pemucat, Pencuci, dan/atau } \\
\text { pengelupas kulit, jenis } \\
\text { hidrogen peroksida dan } \\
\text { natrium hipoklorit }\end{array}$ & $\begin{array}{l}\text { - } \text { kadar maksimal hidrogen peroksida } \\
35 \%(\mathrm{v} / \mathrm{v}) \\
\text { - }{ }^{2} \text { adar maksimal natrium hipoklorit } \\
15 \%(\mathrm{v} / \mathrm{v})\end{array}$ \\
\hline Ayat 5 & $\begin{array}{l}\text { Persyaratan Bahan } \\
\text { Penolong golongan flokulan } \\
\text { jenis nigari, dan golongan } \\
\text { bahan pemucat, pencuci, } \\
\text { dan/atau pengelupas kulit } \\
\text { jenis natrium hipoklorit }\end{array}$ & $\begin{array}{l}\text { a. Nigari } \\
\text { 1. Timbal (Pb) tidak lebih dari } 2 \\
\mathrm{mg} / \mathrm{kg} \\
\text { 2. Merkuri (Hg) tidak lebih dari } 0,1 \\
\mathrm{mg} / \mathrm{kg} \\
\text { 3. Arsen (As) tidak lebih dari } 0,1 \\
\mathrm{mg} / \mathrm{kg} \\
\text { 4. Kadmium (Cd) tidak lebih dari } \\
\text { O,5 mg/kg } \\
\text { 5. Boraks dan Formalin tidak } \\
\text { terdeteksi } \\
\text { 6. Magnesium (Mg) tidak kurang } \\
\text { dari 0,7\%; dan } \\
\text { 7. Klorida (Cl- ) tidak kurang dari } \\
\text { 2,0\%. } \\
\text { b. Natrium Hipoklorit } \\
\text { 1. Timbal (Pb) tidak lebih dari } 2 \\
\text { mg/kg; dan } \\
\text { 2. Merkuri (Hg) tidak lebih dari } 1 \\
\text { mg/kg. }\end{array}$ \\
\hline
\end{tabular}

Dalam proses pengolahan hasil perkebunan adanya pengawasan yang dilakukan oleh BPOM untuk mengetahui kemanan dan mutu yang baik pada makanan, pengawasan tersebut merupakan proses dalam menjamin produksi yang dilaksanakan maka penyimpangan tersebut dapat dikoreksi sehingga apa yang diharapkan dapat tercapai (Fakhri, 2010). Pengawasan mutu dapat juga diartikan sebagai usaha dalam mempertahankan kualitas dari barang dan jasa yang dihasilkan, agar sesuai dengan spesifikasi produk yang telah ditetapkan berdasarkan standar yang telah ditentukan (Fauziati, 2015). Dalam melakukan pengawasan BPOM berperan sebagai upaya antisipasi dengan melalui pengecekan terhadap makanan yang rusak terkhusus untuk makanan kadaluwarsa yang telah beredar dimasyarakat. Dilakukannya hal tersebut guna sebagai pencegahan awal guna untuk melindungi masyarakat (Erhan, 2013).

Jika penggunaan bahan penolong atau bahan tambahan yang digunakan tidak sesuai dengan persyaratan yang telah dijelaskan kedepannya akan mengakibatkan bahaya bagi

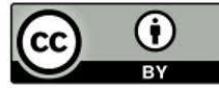


kesehatan konsumen, makanan dan minuman yang mengunakan zat pewarna dan formalin yang tidak langsung memunculkan efek bahaya akibat bakteri tetapi pada jangka panjang akan berakibat fatal pada manusia, seperti: 1) Akut yang merupakan efek pada kesehatan terlihat pada jangka pendek seperti: alergi, mata berair, rasa terbakar, sakit perut, dan sakit kepala yang berlebihan yang mengakibatkan tergangguanya konsentrasi yang sangat tinggi dan menyebabkan Kematian; 2) Keonis merupakan efek pada kesehatan manusia terlihat pada jangka panjang dan berulang seperti: iritasi yang parah, terdapat gangguan pada mata dan pencernaan, hati, ginjal, pankreas, dan sistem syaraf pusat yang bersifat karsinogen (dapat menyebabkan kanker).

\section{Hukuman yang diberikan Kepada Pelaku Tindak Pidana Pengolahan, Peredaran dan atau Pemasaran Hasil Perkebunan yang Membahayakan Kesehatan dan Keselamatan Manusia}

Tindak pidana merupakan perbuatan yang dilarang, dimana larangan tersebut disertai dengan adanya sanksi berupa pidana tertentu bagi barang siapa melanggar larangan tersebut (Putri Gloria Ginting, 2018). Menurut Prof. Moeljatno tindak pidana adalah perbuatan yang dilarang oleh suatu aturan hukum, larangan mana disertai ancaman (sanksi) yang berupa pidana tertentu bagi barang siapa yang melanggar aturan tersebut (Tinggal Click.com, 2016). Pidana mengandung unsur-unsur sebagai berikut: 1) Pidana yang pada dasarnya dalam membentuk unsur pemberian beban dan pengaruh yang memuaskan; 2) Pidana yang diserahkan kepada seseorang ataupun badan yang memiliki kekuasaan (oleh yang berwenang); 3) Pidana tersebut yang telah diberikan kepada seseorang yang telah melakukan tindak pidana menurut UU.

Pidana yang pada hakikatnya menjadi pengenaan penderitaan pada pembuat delik pidana yang diharapkan dapat berpengaruh. Pidana dirasakan oleh pelaku tindak pidana ketika putusan hakim dilaksanakan secara efektif, diharapkan agar terpidana tidak mengulangi perbuatan tersebut lagi. Dengan adanya pemidanaan, maka tujuan pemidanaan baru dapat tercapai. Adapun teori-teori tentang pidana dapat dibagi kedalam 3 (tiga) kelompok teori, sebagai berikut: 1) Teori Absolut (Retributif), menurut teori ini, pidana merupakan akibat yang harus ada sebagai salah satu pembalasan terhadap seseorang yang telah melakukan kejahatan (quia peccatum set), dimana pembenaran pidana terletak pada adanya atau terjadinya kejahatan (Pipin Syarifin, 2000); 2) Teori Relatif (Utilarian), Menurut teori ini bukan hanya sekedar pembalasan terhadap seseorang yang telah melakukan suatu tindakan pidana, namun mempunyai tujuan yang bermanfaat dimana pada dasar pembenarannya ada pidana yang dijatuhkan bukan "quia peccatum est" (orang yang membuat kejahatan), melainkan "nee peccetur" (supaya orang tidak melakukan kejahatan; 3) Teori Gabungan (veriningnings theorieen), bertujuan pemidanaan yang bersifat plural karena menghubungkan prinsip pembalasan dalam satu kesatuan.

Dalam pasal 10 KUHP yang dibagi dalam 2 jenis yaitu: 1) Adanya Pidana Pokok yang didalamnya terdapat Pidana mati; penjara; kurungan; denda; dan Pidana tutupan; 2) Adanya Pidana Tambahan yaitu adanya pencabutan pada hak tertentu; Penyitaan terhadap barang; dan adanya pengumuman terhadap putusan hakim

Dalam UU No 8 Tahun 1999 tentang Perlindungan Konsumen (UUPK) yang dimana pelaku usaha yang menyelenggarakan kegiatan usaha dalam berbagai bidang ekonomi yang dapat dilihat dalam pasal 1 ayat (3). Subyek tindak pidana yang disebut dalam perumusan delik adalah "pelaku usaha". Penuntutan Pidana yang diberikan kepada pelaku usaha dan pengurus pidana pokok yang dapat dijatuhkan pidana denda yang tertuang pada pasal 61 UU No 8 Tahun 1999 tentang ketentuan sanksi yang diberikan kepada pelaku usaha.

Dalam Pasal 62 mengatur tentang pidana denda yang dibebankan kepada pelaku usaha yang melanggar larangan dan akan diberikan pidana penjara paling lama lima tahun dan diberikan ganti rugi sebanyak dua milliar rupiah, dan Pelaku usaha dipidana penjara paling lama 2 tahun atau pidana denda paling banyak lima ratus juta. (Ramdhani, T, 2016). Hukuman yang diberikan kepada pelaku usaha yang melakukan tindak pidana yang membahayakan kesehatan dan keselamatan manusia, dan dapat merusak fungsi lingkungan hidup, yang menyebabkan adanya persaingan usaha tidak sehat dapat diberikan pidana penjara paling lama lima tahun dan 
pemberian denda lima miliar rupiah yang tertuang dalam pasal 110 UU No 39 Tahun 2014 tentang Perkebunan. Sanksi administrasi dalam bentuk penetapan ganti kerugian kepada pelaku tindak pidana sesuai dengan pasal 60 dalam UUPK, pemberian ganti rugi paling banyak dua ratus juta rupiah.

\section{SIMPULAN}

Pelaksanaan hukum berlangsung normal, dan tertib sebagaimana yang terdapat dalam UU Nomor 8 Tahun 1999 bahwa perlindungan konsumen melindungi konsumen dari bahaya hasil perkebunan yang dalam proses pengolahan, pengedaran dan pemasarannya dapat memberikan dampak negatif bagi kesehatan dan keselamatan konsumen yang mengkonsumsinya, yang didalam proses pengolahannya telah dicampurkan bahan tambahan yang dilarang digunakan sebagai bahan tambahan makanan seperti : Asam borat, kalium klorat, minyak nabati yang dibrominasi, nitrifur yang ditetapkan oleh Permenkes Republik Indonesia Nomor 033 Tahun 2012 Tentang Bahan Tambahan Pangan, Jika penggunaan bahan tambahan atau bahan penolong yang digunakan tidak sesuai dengan persyaratan keamanan dan mutu atau pemakaian yang melebihi dan akan berdampak pada kesehatan dan keselamatan manusia terdapat dalam Peraturan Badan Pengawasan Obat dan Makanan Nomor 28 tahun 2019 Tentang Bahan Penolong dalam Pengolahan Pangan.

Pelaku usaha yang melakukan perbuatan melanggar dalam pengolahan, pengedaran dan atau pemasaran yang merugikan kesehatan dan keselamatan manusia, merusak fungsi lingkungan hidup, dan/atau menimbulkan persaingan usaha tidak sehat akan diberikan hukuman berupa sanksi pidana dan sanksi administrasi.

\section{DAFTAR PUSTAKA}

Abdina, M.F. (2019). Analisis Dampak Perkebunan Kelapa Sawit Terhadap Sosial dan Ekonomi Masyarakat di Kabupaten Asahan. Journal of Education, Humaniora and Social Sciences (JEHSS). 2 (2): 292-304.

Miru, A., (2013), Perlindungan Hukum Bagi Konsumen Di Indonesia, Cetakan ke-2, PT Raja Grafindo Persada Jakarta, h.67.

Erhan, (2013), Jurnal: "Perlindungan Konsumen Terhadap Produk Makanan dan Minuman Kadaluarsa (Studi Kasus BPOM), Jurnal Ilmu Hukum Legal Opinion, Edisi 4, Volume 1, 2013.

Fakhri, F. A. (2010), Skripsi: Analisis Pengendalian Kualitas Produksi di PT. Masscom Graphy dalam Upaya Mengendalikan Tingkat Kerusakan Produk Menggunakan Alat Bantu Statistik. Fakultas Ekonomi, Universitas diponegoro, 2010.

Fauziati, N, (2015), Skripsi: Analisis Pengawasan Mutu Produk dengan Menggunakan Metode SPC (Statistical Processing Control). Sekolah Tinggi Agama Islam Negeri (STAIN), Purwokerto, 2015.

Ginting, P.G. (2018), Analisis Penegakan Hukum Pidana Terhadap Tindak Pidana Penipuan Bisnis Online Di Medan, Jurnal Ilmiah Research Sains, Vol. 4 Nomor 2 Juni 2018.

Ali, I.A.P., (2020), Jurnal: "Penadahan Hasil Usaha Perkebunan Ditinjau Dari Undang-Undang nomor 39 Tahun 2014 Tentang Perkebunan", Jurnal Education And Development, Magister Kenotariatan, Fakultas Hukum Universitas Surabaya, 2020.

Imam, G. (2013), Jurnal: “Metode Penelitian Kualitatif”, Universitas Negeri Malang, 2013.

Kadir, A. (2018). Analisis Penetapan Nilai Jual Obyek Pajak Bumi dan Bangunan Sektor Perkebunan sebagai Upaya Peningkatan Sumber Pendapatan Daerah. Journal of Education, Humaniora and Social Sciences (JEHSS). 1 (1): 9-15.

Muchsin. (2003). Perlindungan Dan Kepastian Hukum Bagi Investor Di Indonesia,. Surakarta; Magister Ilmu Hukum Program Pascasarjana Universitas Sebelas Maret.

Nasution, Az. (2001) Hukum Perlindungan Konsumen Suatu Pengantar, Diadit Media, Jakarta, 2001, hlm. 13 dalam Celina Tri Siwi Kristiyanti, Op. Cit., hlm. 2521 Ibid., hlm. 27

Ramdhani, T, (2016). Makalah: Sanksi Pidana Bagi Pelaku Usaha Menurut UU Nomor 8 Tahun 1999 Kebebasan Berkontrak, Kontrak Pemberian Kuasa, Makelar Dan Komisioner, Juni 2016.

Hartono, R., Marlina \& Muaz Zul. Pelaksanaan Peraturan Menteri BUMN Nomor: PER01/MBU/2011 Tentang Penerapan Tata Kelola Yang Baik (Good Corporate Governance) Pada BUMN (Studi

Kasus Di PT Perkebunan Nusantara IV). ARBITER: Jurnal Ilmiah Magister Hukum. 2(1) 2020: 23-32.

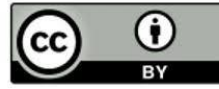


Stanton W.J. (1991). Prinsip Pemasaran, Jilid 2 Edisi Ketujuh. Bandung: Erlangga.

Sugiyono. (2009). Metode Penelitian Kualitatif dan R\&D, Alfabeta, Bandung.

Sutarman Yodo, 2014, Hukum Perlindungan Konsumen, Cetakan ke-8, Grafindo Persada, Jakarta.

Syarifin, P., (2000), Hukum Pidana Di Indonesia, Pustaka Setia, Bandung.

Winda, W., Tedja, K., \& Pakpahan, K. (2020). Tindak Pidana Mengiklankan Hasil Usaha Perkebunan Yang Menyesatkan Konsumen. Journal of Education, Humaniora and Social Sciences (JEHSS), 3(1), 17-25. doi:https://doi.org/10.34007/iehss.v3i1.167

Peraturan Pemerintah Nomor 86 tahun 2019 tentang Keamanan Pangan

Peraturan Pemerintah Republik Indonesia Nomor 58 Tahun 2001 tentang Pembinaan Dan Pengawasan Penyelenggara Perlindungan hukum

Peraturan Badan Pengawasan Obat dan Makanan Nomor 28 Tahun 2019 tentang Bahan Penolong dalam Pengolahan Pangan

Keputusan Menteri Pertanian Nomor 357/Kpts/HK.350/5/2002

Peraturan menteri kesehatan Republik Indonesia nomor 258 tahun 1992

Permenkes Republik Indonesia Nomor 239/Menkes/Per/V/1985 tentang zat warna

Permenkes Republik Indonesia Nomor 033 Tahun 2012 Tentang Bahan Tambahan Pangan

Undang-Undang Nomor 39 Tahun 2014 Tentang Perkebunan

Undang-Undang Nomor 8 Tahun 1999 Tentang Perlindungan Konsumen

Undang-Undang Nomor 18 Tahun 2012 Tentang Pangan

"Pengertian Pengolahan Hasil Perkebunan" (https://paralegal.id/pengertian/pengolahan-hasilperkebunan/, diakses pada 20 september 2020)

"Pengertian data Primer dan Data Sekunder" (https://www.kanalinfo.web.id/pengertian-data-primer-dandata-sekunder, diakses pada 18 november 2019).

"Data Sekunder dalam Penelitian Hum Hormatif" (https://ngobrolinhukum.wordpress.com/2014/08/09/data-sekunder-dalam-penelitian-hukumnormatif/, diakses pada 26 oktober 2019).

"Pengertian Penelitian Hukum Normatif" (https://idtesis.com/pengertian-penelitian-hukum-normatifadalah/, diakses pada 26 oktober 2019).

"Pengertian $\quad$ Tindak dan Jidana Jenis Jenis Delik" (Https://Ilmukita683.Wordpress.Com/2016/11/18/Pengertian-Tindak-Pidana-Dan-Jenis-JenisDelik/, diakses pada 28 juli 2020). 